\title{
Erratum to: Palmitoylethanolamide and luteolin ameliorate development of arthritis caused by injection of collagen type II in mice
}

Daniela Impellizzeri ${ }^{1 \dagger}$, Emanuela Esposito ${ }^{1 \dagger}$, Rosanna Di Paola ${ }^{1}$, Akbar Ahmad $^{1}$, Michela Campolo ${ }^{1}$, Angelo Peli ${ }^{2}$, Valeria Maria Morittu ${ }^{3}$, Domenico Britti ${ }^{3}$ and Salvatore Cuzzocrea ${ }^{1,4^{*}}$

The authors would like to issue an erratum for this article [1], and would like to declare the following competing interests which we inadvertently failed to include in our original publication. The authors would like to apologise for this omission.

In addition, a detailed method for co-ultramicronization process is reported:

\section{Co-ultramicronization process was performed in a} jet-mill equipment endowed with a chamber of $300 \mathrm{~mm}$ in diameter which operates with "spiral technology" and was driven by compressed air at 10-12 bars. The crashing is determined by the high number of collisions that occurs among particles, as a result of the high level of kineticnot mechanical - energy. This process was effective not only in reducing the products particle size, but also in modifying their crystalline structure. Observations by scanning electron microscopy (SEM) shows an intimate intermixing of the two components of the composite, while analysis throw differential scanning calorimetry (DSC) and X-ray diffraction (XRD) have documented the transformation in a new crystalline form different from the original two, definable with "a higher energy content form." The composite shows the following particle size distribution: $96 \%<10 \mu \mathrm{m} ; 80 \%<5 \mu \mathrm{m}$; $40 \%<2 \mu m$ (J Neuroinflammation 2013 10:91).

\footnotetext{
* Correspondence: salvator@unime.it

${ }^{\dagger}$ Equal contributors

'Department of Biological and Environmental Sciences, University of Messina, Messina, Italy

${ }^{4}$ Manchester Biomedical Research Centre, Manchester Royal Infirmary,

University of Manchester, Manchester, UK
}

\section{Competing interests}

Prof. Salvatore Cuzzocrea, researcher on the study team, is a co-inventor on a patent (Application number: 20150057269) with Epitech, along with academic investigators from different institutions and not studied in the above-referenced manuscript. In particular, this patent deals with compositions and methods for the modulation of amidases capable of hydrolysing $\mathrm{N}$-acylethanolamines useable in the therapy of inflammatory diseases. No other authors have competing interests.

\section{Author details}

${ }^{1}$ Department of Biological and Environmental Sciences, University of Messina, Messina, Italy. ${ }^{2}$ Clinical Veterinary Department Alma Mater Studiorum, University of Bologna, Bologna, Italy. ${ }^{3}$ Department of Health Sciences V. le Europa, Campus S. Venuta, Germaneto, Catanzaro 88100, Italy. ${ }^{4}$ Manchester Biomedical Research Centre, Manchester Royal Infirmary, University of Manchester, Manchester, UK.

Received: 20 April 2016 Accepted: 21 April 2016

Published online: 05 May 2016

\section{References}

1. Impellizzeri D, Esposito E, Di Paola R, Ahmad A, Campolo M, Peli A, et al. Palmitoylethanolamide and luteolin ameliorate development of arthritis caused by injection of collagen type II in mice. Arthritis Res Ther. 2013;15:R192.

Submit your next manuscript to BioMed Central and we will help you at every step:

- We accept pre-submission inquiries

- Our selector tool helps you to find the most relevant journal

- We provide round the clock customer support

- Convenient online submission

- Thorough peer review

- Inclusion in PubMed and all major indexing services

- Maximum visibility for your research

Submit your manuscript at www.biomedcentral.com/submit 